\title{
Buy it Now: A Hybrid Internet Market Institution*
}

\author{
Steven Anderson ${ }^{+}$ \\ Daniel Friedman ${ }^{+}$ \\ Garrett Milam ${ }^{\#}$ \\ Nirvikar Singh ${ }^{+}$ \\ Revised April 2004
}

\begin{abstract}
This paper analyzes seller choices and outcomes in approximately 700 recent Internet auctions on eBay. The 'Buy it Now' option that is available in these auctions allows the seller to supplement or replace the auction with a posted price offer. We use a structural model to control for the endogenous conduct of the auction (e.g., number of bids and bidders) as well as product and seller characteristics. Among other results, we find that the 'Buy it Now' option was used more often by sellers with higher ratings (awarded by previous buyers) and sellers offering fewer units; and that posted prices were more prevalent for used items. Sellers obtained higher prices for unused and undamaged items overall, and especially when selling at the 'Buy it Now' price.
\end{abstract}

\footnotetext{
* Acknowledgement. This research has received generous financial support from the UCSC Division of Social Sciences. We are grateful to David Reiley for lending his web crawler PERL script, and to Dan Levin for pointers to the theoretical literature. + University of California, Santa Cruz, California, USA

\#Ryerson University, Toronto, Ontario, Canada
} 


\section{Introduction}

The Internet drastically alters absolute and relative transaction costs, and therefore is having an impact on market institutions. In particular, Internet auctions have gone from being just replacements for swap meets and garage sales, to also being used by large and small retailers as a new way to reach customers. While U.S. e-commerce, estimated at \$59.4 billion in 2003 (U.S. Census Bureau, 2004) still accounts for only 1.6 percent of retail sales, it has been growing rapidly. The leading online auction site is, of course, eBay. All of eBay's sales are not conventional retail transactions, but it is still noteworthy that, in 2003, its net sales, from transaction fees on $\$ 15$ billion in gross revenues, were $\$ 1.2$ billion (Hof, 2003). At the same time, the traditional market institution of posted prices does not seem to be losing its dominant share of retail transactions to the auction format. Amazon and other companies have created very efficient Internet versions of posted price institutions, and the evidence suggests that posted prices are more flexibly and finely adjusted in online settings (Smith et al., 2000). Auctions and posted prices appear to be destined to coexist online, and for overlapping sets of goods.

What are the economic factors that determine the choice of market institution? In this paper we present empirical evidence from recent Internet auctions on eBay that include the option for buyers to purchase immediately at a pre-specified 'Buy it Now' price. As explained below, the option allows sellers to offer what is effectively a hybrid of auction and posted prices, or to choose pure versions of each institution. To untangle the causes and consequences of sellers' choices, we estimate a structural model that predicts auction outcomes, controlling for the (endogenous) conduct of the auction (e.g., the number of bids and bidders), as well as characteristics that are "predetermined," such as the characteristics of the seller, the good, and the transaction (e.g., payment options).

The remainder of the paper is organized as follows. Section 2 reviews some of the most relevant theoretical and empirical literature. Section 3 identifies variables of interest and the causal structure of the empirical model. Section 4 summarizes the data, obtained from over 700 eBay auctions, held during a period of five weeks, for a particular kind of hand-held computer. Section 5 presents results on seller characteristics and choices, while Section 6 presents results on the conduct and outcome of the Internet auctions studied, focusing particularly on the role of the 'Buy it Now' seller option as a hybrid posted price institution. Section 7 concludes with a summary of results, a discussion of their implications, and suggestions for future research. An appendix provides some subsidiary details on the variables and the estimation results.

\section{Research on Market Institutions}

The theoretical literature comparing market institutions is quite diverse. One strand focuses on institutions such as market intermediaries that facilitate search and matching of buyers and sellers; e.g., Rubinstein and Wolinsky (1987, 1990), Gale (1987) and Spulber (1996a,b): see Spulber (1999) for a synthesis. These papers typically assume a simple pricing rule, or assume that a non-cooperative or cooperative bargaining game determines the terms of the transaction. Another strand focuses instead on the pricing strategy of sellers, or the detailed mechanics of the bargaining process, while having little 
to say on how buyers and sellers come together; e.g., Fudenberg and Tirole (1983), and Riley and Zeckhauser (1983). The large literature on auctions, surveyed in McAfee and McMillan (1987) and more recently in Klemperer (2002), can be regarded as a special case of the analysis of market institutions for price agreement.

Comparisons across pricing institutions are less common. For example, Bulow and Klemperer (1996) provide a theoretical analysis of auctions versus some kinds of structured negotiations. Campbell and Levin (2002) also examine the issue of when or when not to use an auction format for selling. Reynolds and Wooders (2003) present a model in which the 'Buy it Now' auction hybrid formats offered by eBay and Yahoo are revenue equivalent to ascending bid auctions if bidders are risk neutral but can raise seller revenue in the presence of bidder risk aversion. Budish and Takeyama (2001) arrive at the same conclusions independently. However, we know of no theoretical literature that directly considers competing simultaneous (or overlapping) auctions held by numerous sellers, in the presence of an option to post prices. Existing theory does not present us with sharply posed testable hypothesis but, as noted below, it is often suggestive.

There are four relevant strands of empirical literature. The first involves laboratory experiments. Plott and Smith (1978) is the first laboratory comparison of market institutions: the oral double auction vs. the posted price institution. Holt (1995) covers some subsequent work. More recently, Cason, Friedman and Milam (2003) contrast the posted price institution with one featuring haggling to determine prices. The authors find that efficiency is lower, sellers' price higher, and prices stickier under haggling than under posted offer pricing.

A second strand features field data from financial markets, in the empirical market microstructure literature that begins with Garman (1976); see e.g., Stoll (2003) for a recent summary. This literature focuses mainly on asset market efficiency, real-time price dynamics, and the roles of various sorts of market makers. Our focus is rather different.

A more recent empirical tradition, pioneered by Lucking-Reiley (1999), has been to conduct "field experiments" by purchasing goods (e.g., collectable trading cards) and reselling them on the Internet, using alternative market institutions. Lucking-Reiley thus tested classical results from auction theory, such as revenue equivalence. Resnick et al. (2003) report a field experiment more directly relevant to our concerns. They find that the effects of seller reputation, murky in most field data so far (including our own), have the predicted positive effect on seller revenues when proper experimental controls are imposed.

Our work falls into the fourth strand, also quite recent. Researchers collect and analyze transactions data from large numbers of closely related Internet sites, typically auctions conducted on web sites operated by eBay, Yahoo or Amazon. This approach can be thought of as collecting involuntary survey data, or as an automated sampling technique. In one example, Houser and Wooders (2000) examine the effect of bidder and seller reputation on auction outcomes, concluding that seller reputations are correlated with auction success in Pentium III microprocessor auctions on eBay. Morgan and Baye (2001) analyze persistent price dispersion in posted price markets on the Internet. The 
timing of bids, and the impact of different methods of specifying auction deadlines are studied by Roth and Ockenfels (2002). They propose that, given eBay's auction format, late bidding may be rational for strategic agents. Bajari and Hortaçsu (2003) also provide a theoretical analysis of late bidding, and independently reach some of the same empirical conclusions as Roth and Ockenfels, using eBay data. They also examine issues of the winner's curse and the impact of reserve prices. Ockenfels and Roth (2003) further examine the ending time issue, providing a theoretical analysis as well as a comparison of bidding behavior under different rules, using data from eBay and Amazon. LuckingReiley et al. (2000) use data collected from eBay auctions of one-cent coins to study determinants of price. We describe the details of this methodology in Section 4, since we use a version of the web-crawling program used in that work.

\section{Key Variables and Hypotheses}

The existing literature suggests a list of variables to be included in the empirical analysis, and, in some cases, provides specific hypotheses. The appropriate dimensions for our analysis of the institutional structure of auctions are suggested by the literature. The variables can be put into several general categories, as follows:

\section{Product characteristics}

Hedonic theory (Lancaster, 1971; Rosen, 1974) distinguishes quality characteristics (for which all consumers have ordinally equivalent preferences) from niche characteristics (for which different consumer segments may have marginal valuations with opposite signs.) Quality increments ceteris paribus imply higher transaction prices.

For our data, higher quality should be associated with "new" or "undamaged" products, and (due to rapid economic obsolescence) with earlier transaction dates. Niche characteristics, such as color or shipping location, are probably best dropped from the analysis because we have no demographic information on buyers.

\section{Seller characteristics}

The information regarding sellers that is available in an online auction is indirectly observed, and thus imperfect, and furthermore is often selected by the seller herself. Information regarding seller characteristics, apart from that provided via the seller choices (discussed below), includes the feedback ratings provided by previous customers and the number of auctions the seller is currently running. The seller ratings may work in at least two dimensions, with a higher absolute number of ratings indicating a longer history in the auction site and the relative number of positive ratings more directly identifying seller quality.

Although not directly the result of seller choices, the ratings are still imperfect signals of underlying characteristics, such as the trustworthiness of the seller to accurately represent the product and follow through in the transaction in good faith. Empirically, it is important to control for simultaneous seller choices as well. For instance, a higher volume seller may appear more stable and professional, thus attracting more bidders and increasing transaction price, but sellers with many similar items to sell may utilize 'Buy it Now' pricing to price discriminate based on the relative patience or 
reservation prices of bidders, perhaps resulting in lower prices, on average. Theoretically, a trustworthier seller will obtain higher prices in a separating equilibrium ceteris paribus (Fudenberg and Tirole, 1991).

\section{Seller choices: General}

Investments that signal trustworthiness, once sunk, presumably will increase transaction price, since otherwise the seller would have little reason to make them: these investments are therefore part of a separating equilibrium where the seller's characteristics are unknown, ex ante. Such investments might possibly include use of photographs of the item, more detailed descriptions, buying a "featured" billing, or links to websites with further information regarding the seller. A higher public reservation price could serve a similar purpose in signaling product quality. The seller's choice of quantity to put up in a single auction would have no effect on price (other than possibly signaling trustworthiness) in a thick market. In a thin market it would tend to reduce the average transaction price. If buyers are price takers, a higher hidden reservation price will trade off a lower probability of a sale against a higher transaction price conditional on a sale. If buyers react to a hidden reservation price per se, there could be other effects. ${ }^{1}$

\section{Seller Choices: Buy it Now and Posted Offer}

We examine this seller choice separately since it is a focus of the analysis. It should be noted that the seller can exactly replicate a posted offer by offering a 'Buy it Now' price and an equal public reserve price. Other forms of 'Buy it Now' approximate posted prices to a greater or lesser degree.

The choice of posted price vs. straight auction mainly involves a trade-off between (a) expected losses due to mis-pricing a posted price, against (b) reduced demand due to buyers' higher participation costs in auctions. The higher participation costs arise from the loss of immediacy-buyers must wait until the end of an auction to know whether they transacted - and flexibility - they should stand ready to make last second bids, or else have specialized software. Hence sellers who have relatively precise beliefs about demand will tend to prefer posted price or "Buy it Now". If some sellers use a posted price and other sellers use straight auctions, then in a separating equilibrium, the buyers who are more risk averse and/or impatient will go for the 'Buy it Now' price and the other buyers will participate in the full auction. This would be an interior equilibrium. On the other hand, sufficiently strong network externalities point to a corner equilibrium. Buyers prefer to go to a market format where there are many sellers, and sellers prefer to offer a format that attracts many buyers.

\footnotetext{
${ }^{1}$ In a field experiment, Katkar and Lucking-Reiley (2000), comparing public and private reserve prices, found that the use of a private reserve reduces both the probability of a sale and the transaction price. One caveat to these results is that the authors found some informal evidence that sellers were using the private reserve to circumvent eBay's fee structure by personally contacting high bidders after unsuccessful auctions. Anderson et al. (2004), in a companion paper to the current piece, found that the probability of a sale was lower, but the transaction price higher, when a private reserve price was used.
} 


\section{Market history}

As the auction unfolds, further information may be revealed. For example the number of realized bids within a given time period may be a proxy for the number of potential bidders.

Figure 1 schematically shows the sequence of decisions that we will analyze.

\section{Figure 1: Decision Making Sequence in an Auction}

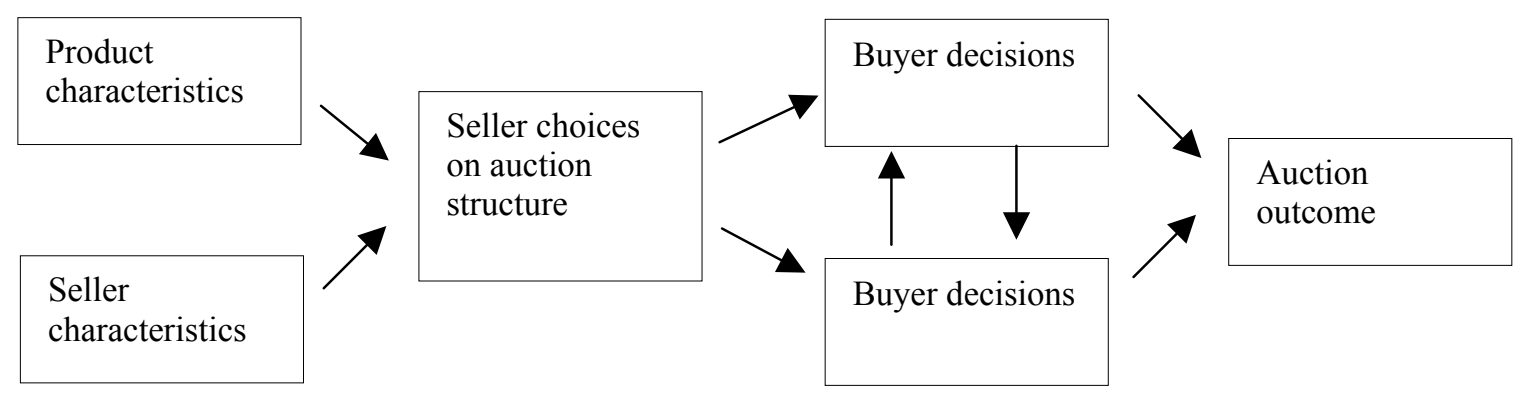

We take the product and seller characteristics as exogenous, determining the seller choices on auction structure. These choices, together with exogenous buyer preferences, determine the dynamic course of the auction (or hybrid market when the 'Buy it Now' option is used) and the ultimate outcomes.

Our strategy for analyzing the data accordingly has two parts. First, we use the observable product and seller characteristics to explain the main seller choices, using Ordinary Least Squares (OLS) for continuous choices and Logit for binary choices. Section 5 presents those results, and notes when they support or cast doubt on the testable hypotheses presented above. Next, we use relevant exogenous characteristics, as well as instruments for the endogenous seller choices, to explain the market outcomes, via Two Stage Least Squares (2SLS). Section 6 presents the results for this aspect of the auction.

\section{Data Overview}

Our hypotheses are best tested on a reasonably large sample of auctions for selling a homogeneous good over a short period of time. Therefore we gathered data from eBay, the largest Internet auction site, for one of the highest volume (at the time) and most homogenous items, the Palm Vx handheld computer.

\section{eBay Auction Rules}

A review of eBay's basic rules is in order before presenting the data. The seller provides information on the item, such as a description and picture, terms of payment and shipping, and chooses the duration of the auction, either $3,5,7$, or 10 days. The seller also chooses a minimum first bid (starting price), and whether to enter a private reserve price. (Potential buyers know when a private reserve price exists but don't know its value 
until someone bids above it.) Sellers may also provide links to their own "home pages" on the web, which can be a source of further information for buyers.

Potential buyers can bid on any item they find on eBay's web site, and bid histories are available to them. The auction ends at the pre-specified time, and the item goes to the highest bidder at the highest bid price. Shipping and payment are left up to the buyer and seller, although eBay services here are available at an additional fee. Finally, eBay also provides a record of comments about sellers, so that sellers can potentially build and maintain reputations. Potential buyers have access to these comments, as well as all seller-provided information.

The seller also can specify a 'Buy it Now' price. By so doing, the seller commits to sell the item immediately to any buyer who accepts that price, thus ending the auction early. The 'Buy it Now' option is extinguished (and disappears from the item's auction site) when any buyer enters a bid that is at least as great as the minimum first bid, even if the first bid is lower than the 'Buy it Now' price. The seller can prevent this by specifying a starting price (or a private reserve price) at or above the 'Buy it Now' price.

As noted earlier, such price combinations are equivalent to a posted price. (By using a high private reserve price to "protect" the 'Buy it Now' option, the seller allows bidding to continue, but fruitlessly. Buyer comments suggest that they find the practice annoying and they may avoid the auction. Using a high starting price is just as effective and more transparent.) Used by itself, the 'Buy it Now' option creates a hybrid institution, a mix of an auction and a posted price, with buyer behavior determining which of the two institutions is activated for the transaction.

\section{The Data}

We collected data on 1211 Palm Vx auctions on eBay from August 6 to September 11, 2001 using a web-crawling "spider" similar to that described in LuckingReiley et al (2000). In 24 cases, we could not determine whether or not the auction started with a 'Buy it Now' option, and these auctions were eliminated. Of the remaining 1177 auctions, 1008 were successfully completed, ending in a sale. In this paper, we focus on completed auctions. A companion paper (Anderson et al., 2004) includes an analysis of the differences between auctions that resulted in a sale and those that did not. The main conclusions are that auctions involving a private reserve price were much less likely to end in a sale and that more experienced sellers in our sample very rarely failed to sell an item. Additionally, we found that a sale was somewhat more likely when sellers made 'Buy it Now' offers.

Furthermore, of the 1008 completed auctions, 286 were conducted by two high volume sellers, whom we term "retailers." We omit these auctions from our sample as well, leaving 722 observations for analysis. We analyze the retailers separately, in Anderson et al. (2004), because their behavior differs importantly from the low volume sellers. In brief, the retailers had higher ratings, and they always used the pure 'Buy it Now' option. Both retailers used minimal (\$0.01) "first bids" (starting prices) and avoided private reserve prices. Thus the retailers in our sample took full advantage of the hybrid, 'Buy it Now' institution by using it to provide a quick sale to impatient buyers, 
yet encouraging as much bidding up of the price as possible if no impatient buyer happened to be shopping at the time.

Table 1 presents the average values of the variables. The first column reports on the full sample of completed transactions, the second and third report the sub-samples for which the seller did not or did use the 'Buy it Now' option, and the last two divide the previous sub-sample according to whether the 'Buy it Now' option was exercised. The sample sizes in appear in the bottom row. Complete definitions of variables appear in the Appendix.

Table 1: Sample and Sub-sample Means

\begin{tabular}{lccccc}
\hline \multicolumn{1}{c}{ Variable } & All Sales & $\begin{array}{c}\text { "Buy it Now" } \\
\text { not Offered }\end{array}$ & $\begin{array}{c}\text { Buy it Now" } \\
\text { Offered }\end{array}$ & $\begin{array}{c}\text { Buy it Now" } \\
\text { not Accepted }\end{array}$ & $\begin{array}{c}\text { Buy it Now" } \\
\text { Accepted }\end{array}$ \\
\hline Product Characteristics & & & & & \\
\hline NEW & 0.389 & 0.376 & 0.420 & 0.496 & 0.319 \\
DAMAGE & 0.026 & 0.024 & 0.033 & 0.017 & 0.055 \\
EXTRAS & 0.436 & 0.414 & 0.491 & 0.521 & 0.451 \\
QUANTITY & 1.252 & 1.337 & 1.0471 & 1.083 & 1 \\
DAYS806 & 18 & 18 & 18 & 18 & 19 \\
\hline Seller Characteristics & & & & & \\
SINGLSLR & 0.440 & 0.465 & 0.382 & 0.413 & 0.341 \\
MULTSLR & 0.298 & 0.278 & 0.344 & 0.273 & 0.440 \\
FREQSLR & 0.262 & 0.257 & 0.274 & 0.314 & 0.220 \\
RETAILER & 0.025 & 0.030 & 0.015 & 0.013 & 0.017 \\
NEGRATIO & 3.538 & 3.214 & 4.319 & 4.110 & 4.597 \\
LNSLRTNG & 0.440 & 0.465 & 0.382 & 0.413 & 0.341 \\
\hline Seller Choices & & & & & \\
\hline SLRHOME & 0.129 & 0.106 & 0.184 & 0.182 & 0.187 \\
STARTPRC & $\$ 79.97$ & $\$ 57.88$ & $\$ 133.10$ & $\$ 81.45$ & $\$ 201.78$ \\
LOWSTPRC & 0.395 & 0.455 & 0.25 & 0.438 & 0 \\
PRIVTRES & 0.255 & 0.235 & 0.302 & 0.273 & 0.341 \\
FEATURED & 0.026 & 0.037 & 0 & 0 & 0 \\
DSCLNGTH & 4165 & 4266 & 3922 & 4144 & 3628 \\
IMAGE & 0.713 & 0.661 & 0.840 & 0.860 & 0.813 \\
SCRPYDUM & 0.722 & 0.692 & 0.792 & 0.810 & 0.769 \\
POSTDPRC & 0.125 & 0 & 0.425 & 0.008 & 0.979 \\
STRTBYNW & 0.294 & 0 & 1 & 1 & 1 \\
BYNOWPRC & $\$ 217.16$ & & $\$ 217.16$ & $\$ 227.97$ & $\$ 202.79$ \\
\hline Auction Outcomes & & & & & \\
\hline DURATION & 4.875 & 5.156 & 4.198 & 5.645 & 2.274 \\
ENDBYNOW & 0.139 & & 0.429 & 0 & 1 \\
NUMBIDS & 15.878 & 18.910 & 8.585 & 13.198 & 2.451 \\
UNIQBIDR & 9.026 & 10.669 & 5.075 & 7.537 & 1.802 \\
WINBID & $\$ 199.01$ & $\$ 197.96$ & $\$ 201.53$ & $\$ 201.35$ & $\$ 201.78$ \\
\hline Sample Size & $\mathbf{7 2 2}$ & $\mathbf{5 1 0}$ & $\mathbf{2 1 2}$ & $\mathbf{1 2 1}$ & $\mathbf{9 1}$ \\
\hline
\end{tabular}


The observable product characteristics - whether the item is new, whether it is damaged or includes any extra accessories - are dummy variables. ${ }^{2}$ Here quantity refers to the number of units offered in a particular auction; the mode is always 1, and large quantities are quite rare when 'Buy it Now' was offered. Days806 is the time trend; auctions starting later tend to yield lower prices due to economic obsolescence. For new items, which constitute $38.9 \%$ of the sample, the 'Buy it Now' option is less likely to be offered, but more likely to be accepted, as compared to the whole sample.

The observable seller characteristics unfortunately do not include risk aversion or time preference, but they do include the number of auctions conducted during the sample period (MULTSLR codes 2-10 auctions and FREQSLR codes 11-50) and buyer ratings. Ratings are long strings of comments, which we summarize in two variables: NEGRATIO (the ratio of negative to total comments), and LNSLRTNG (natural log of positive comments net of negative comments). Thus lower NEGRATIO and higher LNSLRTNG indicate two aspects of better seller reputation. The mean ratings across sub-samples in Table lindicate slightly better seller reputations, on average, in the non'Buy it Now' sub-sample. However, the nature of the link between reputation and choice of 'Buy it Now' is altered once the structural model is estimated.

Seller choices are summarized in the next section of the table. Overall, $12.9 \%$ of the auctions display links to homepages. Minimum bid prices average about $\$ 80$, but diverge for accepted and not accepted "Buy it Now", probably reflecting the fact that this option is accepted more often when it is effectively a posted price (POSTDPRC $=1$ ). Private reserve prices are used in $25.5 \%$ of all auctions, and more frequently when a 'Buy it Now' price is accepted. Sellers offer secure payment procedures (SCRPYDUM=1) and a picture of the product (IMAGE $=1$ ) in about $70 \%$ of auctions, but rarely pay for a place in eBay's featured items (FEATURED=1). Description lengths average about 4,000 characters but are, for no obvious reason, slightly longer in auctions where the option is not accepted. Some $29.4 \%$ of auctions in our sample offer the 'Buy it Now' option; of these $42.5 \%$ actually are posted price. However, of those where "Buy it Now" was accepted, $97.9 \%$ are posted price.

The last part of the table contains the auction outcomes, including average duration (about 5 days except when the 'Buy it Now' option is accepted), the number of bids, number of unique bidders, and the winning bid. Winning bids averaged $\$ 199$, and tended to be about $\$ 3.50$ higher for sellers offering the 'Buy it Now' option, whether or not it was accepted.

As noted earlier, our regressions are for a set of 722 auctions, excluding two very high-volume sellers. We also separately analyze sub-samples: auctions where the 'Buy it Now' option was not used (510), those where it was (212), 'Buy it Now' auctions in which there was an auction and the 'Buy it Now' price was not the transaction price (121), and 'Buy it Now' auctions which ended through the use of the option, so that effectively no auction took place. It is important to keep in mind that all but one of these 91 auctions in this final sub-sample were auctions where the seller effectively used 'Buy it Now' to post a price. Thus, the 'Buy it Now' option was accepted, but the only bidding

\footnotetext{
${ }^{2}$ Where there was any ambiguity, we consistently assumed that the characteristic (newness, damage, or inclusion of accessories) was not present.
} 
alternative for the buyer was to try a different seller. For the remaining 121 auctions that started with 'Buy it Now,' only one also had a posted price. ${ }^{3}$

\section{Seller Characteristics and Choices}

Tables 2 and 3 present OLS and Logit regression results for seller choices, using 722 observations of auction sales by non-retailers. The explanatory variables are the exogenous product and seller characteristics, omitting the dummy variable for FREQSLR (21-50 auctions). The first column shows that the starting bid (or minimum price) is higher (on the order of \$50-60) for the infrequent sellers and slightly higher for sellers with better reputations. The other variables (time trend DAYS806, dummies for new, damaged, extras, etc.) generally enter with the expected sign but are insignificant.

\section{Table 2: How Seller and Product Characteristics Influence Seller Choices:} OLS Regression Results

\begin{tabular}{llll}
\hline \multirow{2}{*}{$\begin{array}{l}\text { Independent } \\
\text { Variable }\end{array}$} & \multicolumn{3}{c}{ Dependent Variables } \\
\cline { 2 - 4 } NEW & $\begin{array}{c}\text { Starting } \\
\text { Price }\end{array}$ & $\begin{array}{c}\text { Description } \\
\text { Length }\end{array}$ & $\begin{array}{c}\text { 'Buy it Now' } \\
\text { Price }\end{array}$ \\
& 1.50 & -406 & $20.02^{* * *}$ \\
DAMAGE & $(0.226)$ & $-(1.309)$ & $(3.877)$ \\
EXTRAS & -20.91 & -31.00 & $-32.16^{* *}$ \\
& $-(1.119)$ & $-(0.037)$ & $-(2.324)$ \\
QUANTITY & 4.36 & -334 & 3.59 \\
& $(0.681)$ & $-(1.042)$ & $(0.628)$ \\
DAYS806 & 0.71 & 138 & $-11.10^{* * *}$ \\
& $(0.273)$ & $(0.755)$ & $-(2.857)$ \\
SINGLSLR & -0.16 & -7.00 & 0.15 \\
& $-(0.502)$ & $-(0.398)$ & $(0.555)$ \\
MULTSLR & $51.81 * * *$ & $-2835^{* * *}$ & $22.08^{* * *}$ \\
& $(6.817)$ & $-(8.062)$ & $(3.425)$ \\
NEGRATIO & $59.77^{* * *}$ & $-1712^{* * *}$ & 10.39 \\
& $(7.552)$ & $-(4.261)$ & $(1.607)$ \\
LNSLRTNG & 5.45 & $22830^{* * *}$ & $-453.25^{* * *}$ \\
& $(0.148)$ & $(6.921)$ & $-(5.143)$ \\
Sample Size & $4.27 * *$ & $234 * * *$ & $-2.64^{* *}$ \\
\hline
\end{tabular}

Note: 1 to 3 asterisks represent $10 \%, 5 \%, 1 \%$ significance, respectively

\footnotetext{
${ }^{3}$ The explanations for why someone might bid higher than a posted price may be that they did not understand it to be a posted price, given the hybrid nature with a buy now offer or the buyer(s) may want to signal the seller that if the auction is unsuccessful they would be willing to purchase the item at a postauction discounted price. The one observation where the final price was not equal to the posted price may simply be due to the seller completing this type of "side agreement" before the termination of the auction and letting it become the officially posted, final price.
} 
Column 2 indicates that frequent sellers and sellers with home pages tended to have longer product descriptions. NEGRATIO and LNSLRTNG coefficients are both positive, indicating an ambiguous effect of seller reputation on description length. The third column of Table 2 only encompasses the complementary sub-sample, the 212 auctions that had the 'Buy it Now' option. As one would expect, items that are characterized as 'new' have higher 'Buy it Now' prices, while items identified as damaged have lower 'Buy it Now' prices. Auctions involving higher quantities have lower 'Buy it Now' prices, while sellers with a high ratio of negative comments set lower 'Buy it Now' prices. Infrequent sellers tend to set higher 'Buy it Now' prices.

\section{Table 3: How Seller and Product Characteristics Influence Seller Choices: Logit Results}

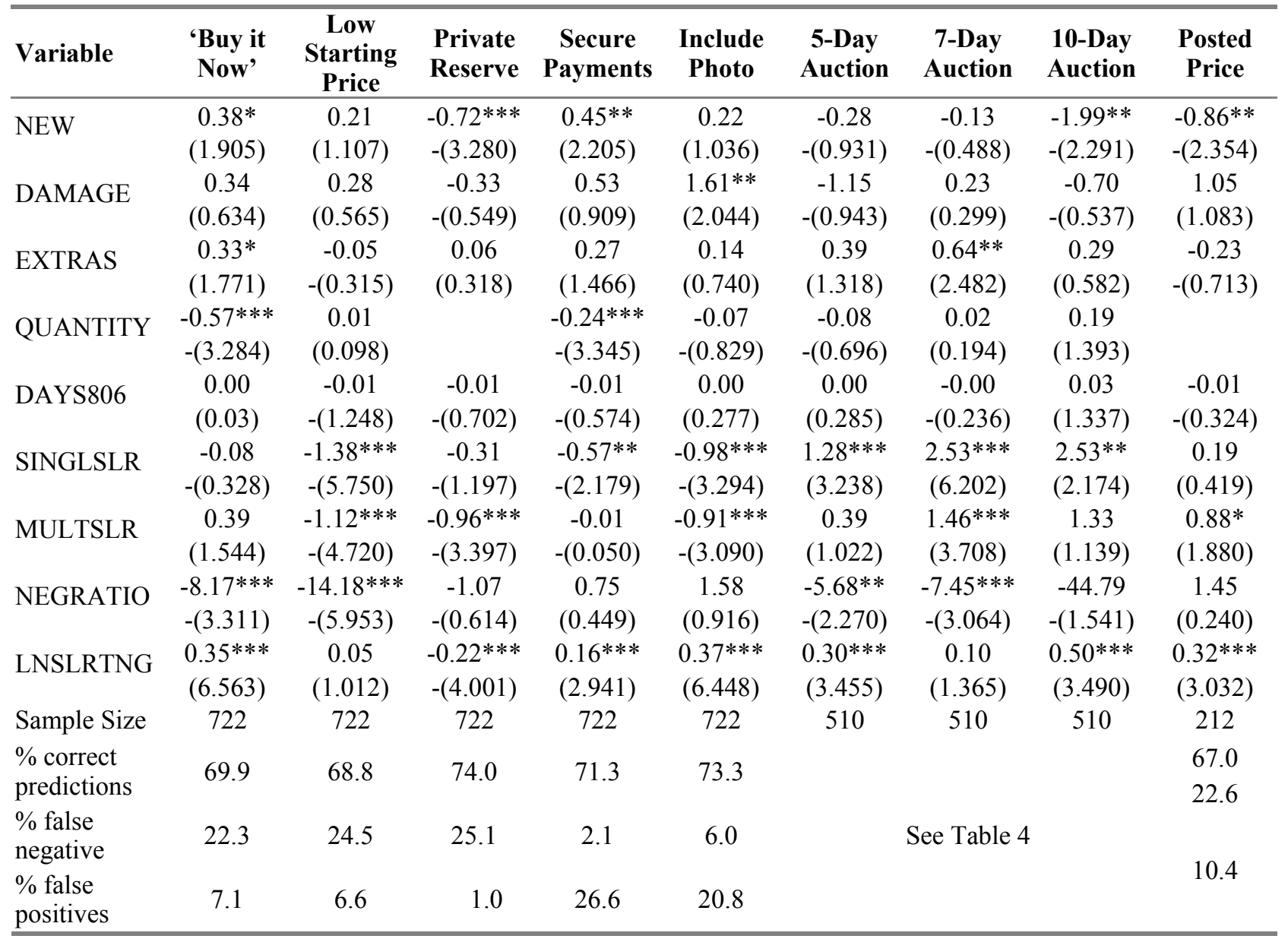

Notes: (1) Coefficients are reported, with t-statistics in parentheses. (2) 1 to 3 asterisks represent 10, 5, 1\% significance, respectively. (3) Seller choice of a 3-day auction is the omitted category for auction duration choices

The first column of Table 3 confirms that the 'Buy it Now' option is chosen more often by sellers with better reputations. Auctions with larger quantities are also less likely to use the 'Buy it Now' option. New items are more likely to be sold with the 'Buy 
it Now' option, though the significance level is marginal. Column 2 includes results for the dummy variable that represents the discrete seller choice of whether or not to start the bidding at an initial price above or below $\$ 50$. The results for the impacts of seller characteristics on this decision are similar to those for the continuous choice of a starting price level presented in the first column of Table 2, except that the ratio of negative comments appears to have a significant, negative impact on this discrete choice, while it was the overall seller rating that had a positive impact on the continuous choice of the starting price.

Column 3 of Table 3 indicates that a private reserve price was used less often for new items and was used less often by infrequent sellers. Column 4 indicates that the seller's decision to incorporate a secure payment method (credit card, PayPal, eBay Online Payments, etc.) was more likely if the item was new, if the seller had a better rating, and if the seller had a home page. This choice was less likely for sellers who had just a single auction in the sample, and also if more than one item was being offered in the auction. Column 5 shows that items described as damaged were more likely to have a photo, perhaps to reassure potential buyers. Frequent sellers were more likely to use photographs, as were sellers with home pages. Higher rated sellers were more likely to use photographs.

Columns 6-8 present the results of a multinomial Logit regression for the choice of auction length. Since auctions with the 'Buy it Now' option end at an endogenously determined time, these were excluded. The results are presented relative to the category of an auction length of three days (the minimum in the absence of "Buy it Now"). If the item was new, the chosen length of the auction tended to be shorter than 10 days. The 4resence of extra accessories tended to make the auction length of 7 days more popular. Sellers who conducted only one auction in the sample period tended to choose auctions longer than 3 days. The two seller quality variables had conflicting impacts on the auction length. Table 4 reports actual and predicted outcomes for the multinomial Logit.

Table 4: Frequencies of Actual and Predicted Outcomes for Columns 6-8, Table 3

\begin{tabular}{|c|c|c|c|c|c|}
\hline \multirow{2}{*}{ Actual } & \multicolumn{5}{|c|}{ Predicted } \\
\hline & $\mathbf{0}$ & 1 & 2 & 3 & Total \\
\hline $\mathbf{0}$ & 132 & 3 & 63 & 0 & 198 \\
\hline 1 & 37 & 7 & 54 & 0 & 98 \\
\hline 2 & 38 & 2 & 149 & 1 & 190 \\
\hline 3 & 2 & 1 & 20 & 1 & 24 \\
\hline Total & 209 & 13 & 286 & 2 & 510 \\
\hline
\end{tabular}

The last column of Table 3 reflects only the 212 auctions that involved the 'Buy it Now' option, just like the last column in Table 2. This last column shows that the choice to create a posted price (usually by entering a starting price equal to the 'Buy it Now' price) is less likely for new items and more likely for experienced sellers (as indicated by LNSLRTNG). 


\section{Auction Outcomes}

We now examine how observed seller characteristics and seller choices influence auction outcomes. We are particularly interested in how the 'Buy it Now' option affects final price, i.e., the winning bid. For example, if the 'Buy it Now' option were used by mainly by impatient sellers, then we would see 'Buy it Now' auctions bringing lower average prices. Of course, we must control for seller choices and characteristics, and also for the conduct of the auction itself. For example, if the final price were affected by the excitement generated by the bidding process, then we would make incorrect inferences if we ignored the number of bids. Consequently we report 2SLS results using instruments for the auction conduct variables - the duration, the number of bids and the number of unique bidders - as well as for seller choices. ${ }^{4}$

Table 5 presents the 2SLS coefficient estimates for final price in the 722 auction sales, excluding retailers. The second and third columns separate the cases in which the 'Buy it Now' option was not and was offered, and the last two columns separate the cases in which it was not or was accepted when offered. Note that the variables for whether an auction ended with 'Buy it Now,' the number of bids, and the number of bidders are always endogenous and we always instrumented for these. The variable indicating the duration of the auction was only endogenous in the 'Buy it Now' sub-samples, in which case we also instrumented for it.

Units described as new command on average a significant $\$ 6.80$ premium overall, and a marginally significant $\$ 16.74$ premium when the 'Buy it Now' option was accepted. Units described as even slightly damaged go at a marginally significant $\$ 17.12$ discount overall, and a very significant $\$ 62.39$ discount when the 'Buy it Now' option was accepted. Larger quantities in a single auction lead to a significant $\$ 4.18$ average discount overall; as noted earlier, larger quantities are seldom offered in tandem with the 'Buy it Now' option. Overall, the marginally significant time trend lowers price 21 cents per day on average, but it is insignificant in the sub-sample where the option was offered.

Infrequent sellers obtain significantly lower prices (by about \$10) than the Frequent sellers (dummy omitted) overall. The effect goes strongly the opposite way in the 91 auctions ending with an accepted 'Buy it Now' price. As explained in the Appendix, the reason is that almost all these sellers were actually using a posted price, so the higher realized price reflects a tradeoff against the lower probability of sale.

Seller reputation as measured by NEGRATIO is insignificant overall, but has a large and significant impact in expected direction in the last sub-sample. The other reputation measure, LNSLRTNG measure is significantly and surprisingly negative overall, but is insignificant in the last sub-sample. The reputational measures both have multicollinearity problems, and the second measure is also closely related to seller experience. Hence reputation inferences are problematic in our data (and in other field data collected passively, as noted in our literature review in connection with Resnick et al., 2003).

\footnotetext{
${ }^{4}$ See the Appendix for details of instrument fits and a comparison of OLS and 2SLS estimates.
} 
Table 5: 2SLS Regressions of Outcome (Value of Winning Bid)

\begin{tabular}{|c|c|c|c|c|c|}
\hline Variable & All Sales & No BuyNow & Only BuyNow & BuyNow Rej. & BuyNow Acc. \\
\hline NEW & $\begin{array}{c}6.799 * * * \\
(3.272)\end{array}$ & $\begin{array}{l}7.429 * * \\
(2.378)\end{array}$ & $\begin{array}{l}7.058^{* *} \\
(2.288)\end{array}$ & $\begin{array}{c}3.201 \\
(0.642)\end{array}$ & $\begin{array}{l}16.744^{*} \\
(1.922)\end{array}$ \\
\hline DAMAGE & $\begin{array}{l}-17.117^{*} \\
-(1.756)\end{array}$ & $\begin{array}{l}-20.510 \\
-(1.448)\end{array}$ & $\begin{array}{l}-16.662 \\
-(1.304)\end{array}$ & $\begin{array}{l}16.909 \\
(0.859)\end{array}$ & $\begin{array}{c}-62.391 * * * \\
-(3.291)\end{array}$ \\
\hline EXTRAS & $\begin{array}{c}3.172 \\
(1.297)\end{array}$ & $\begin{array}{c}6.092 \\
(1.614)\end{array}$ & $\begin{array}{c}2.379 \\
(0.914)\end{array}$ & $\begin{array}{c}-3.027 \\
-(0.733)\end{array}$ & $\begin{array}{c}8.943 \\
(0.911)\end{array}$ \\
\hline QUANTITY & $\begin{array}{c}-4.184 * * * \\
-(3.396)\end{array}$ & $\begin{array}{c}-3.685^{* * *} \\
-(2.772)\end{array}$ & $\begin{array}{c}-1.719 \\
-(0.533)\end{array}$ & $\begin{array}{c}-5.071 \\
-(1.075)\end{array}$ & \\
\hline DAYS806 & $\begin{array}{l}-0.210^{*} \\
-(1.954)\end{array}$ & $\begin{array}{l}-0.281^{*} \\
-(1.865)\end{array}$ & $\begin{array}{c}0.069 \\
(0.461)\end{array}$ & $\begin{array}{c}0.125 \\
(0.500)\end{array}$ & $\begin{array}{c}0.168 \\
(0.482)\end{array}$ \\
\hline SINGLSLR & $\begin{array}{c}-9.498 * * * \\
-(2.941)\end{array}$ & $\begin{array}{c}-13.879 * * * \\
-(2.968)\end{array}$ & $\begin{array}{c}8.744 \\
(1.530)\end{array}$ & $\begin{array}{c}-1.487 \\
-(0.160)\end{array}$ & $\begin{array}{c}40.203 * * * \\
(2.701)\end{array}$ \\
\hline MULTSLR & $\begin{array}{c}-11.673 * * * \\
-(3.762)\end{array}$ & $\begin{array}{c}-15.524 * * * \\
-(3.467)\end{array}$ & $\begin{array}{c}2.474 \\
(0.479)\end{array}$ & $\begin{array}{c}-0.628 \\
-(0.063)\end{array}$ & $\begin{array}{c}26.371 * \\
(1.952)\end{array}$ \\
\hline NEGRATIO & $\begin{array}{l}-32.743 \\
-(1.480)\end{array}$ & $\begin{array}{l}-34.522 \\
-(1.260)\end{array}$ & $\begin{array}{l}29.200 \\
(0.459)\end{array}$ & $\begin{array}{c}162.464^{*} \\
(1.691)\end{array}$ & $\begin{array}{c}-326.95 * * \\
-(2.398)\end{array}$ \\
\hline LNSLRTNG & $\begin{array}{c}-2.005 * * * \\
-(3.530)\end{array}$ & $\begin{array}{l}-2.101 * * \\
-(2.504)\end{array}$ & $\begin{array}{l}-2.343 * * \\
-(2.330)\end{array}$ & $\begin{array}{c}-2.173 \\
-(1.525)\end{array}$ & $\begin{array}{c}-1.240 \\
-(0.511)\end{array}$ \\
\hline SLRHOME & $\begin{array}{c}-2.194 \\
-(0.641)\end{array}$ & $\begin{array}{c}-0.794 \\
-(0.134)\end{array}$ & $\begin{array}{l}8.386^{* * *} \\
(2.324)\end{array}$ & $\begin{array}{c}7.399 \\
(0.978)\end{array}$ & $\begin{array}{c}29.557 * * * \\
(3.516)\end{array}$ \\
\hline STARTPRC & $\begin{array}{l}-0.139 \\
-(1.016)\end{array}$ & $\begin{array}{c}-0.034 \\
-(0.181)\end{array}$ & $\begin{array}{c}0.140 \\
(0.716)\end{array}$ & $\begin{array}{l}0.596^{*} \\
(1.784)\end{array}$ & \\
\hline SQRSTPRC & $\begin{array}{c}0.0015^{* * *} \\
(3.444)\end{array}$ & $\begin{array}{c}0.0012 * \\
(1.732)\end{array}$ & $\begin{array}{c}0.0010^{*} \\
(1.864)\end{array}$ & $\begin{array}{c}0.000 \\
-(0.122)\end{array}$ & \\
\hline LOWSTPRC & $\begin{array}{c}-5.761 \\
-(0.761)\end{array}$ & $\begin{array}{c}-2.589 \\
-(0.253)\end{array}$ & $\begin{array}{l}14.694 \\
(1.173)\end{array}$ & $\begin{array}{c}36.070^{*} \\
(1.783)\end{array}$ & \\
\hline PRIVTRES & $\begin{array}{c}10.008 * * * \\
(4.381)\end{array}$ & $\begin{array}{c}11.147 * * * \\
(2.994)\end{array}$ & $\begin{array}{l}-1.205 \\
-(0.346)\end{array}$ & $\begin{array}{c}16.975 * * * \\
(2.805)\end{array}$ & $\begin{array}{l}-14.774 \\
-(1.104)\end{array}$ \\
\hline DSCLNGTH & $\begin{array}{c}0.0009^{*} \\
(1.818)\end{array}$ & $\begin{array}{c}0.0012 * \\
(1.782)\end{array}$ & $\begin{array}{c}0.001 \\
(1.095)\end{array}$ & $\begin{array}{c}0.001 \\
(1.607)\end{array}$ & $\begin{array}{c}0.000 \\
(0.037)\end{array}$ \\
\hline IMAGE & $\begin{array}{l}-0.539 \\
-(0.151)\end{array}$ & $\begin{array}{c}-2.233 \\
-(0.499)\end{array}$ & $\begin{array}{c}0.421 \\
(0.129)\end{array}$ & $\begin{array}{c}5.858 \\
(0.850)\end{array}$ & $\begin{array}{l}10.101 \\
(0.970)\end{array}$ \\
\hline SCRPYDUM & $\begin{array}{l}-4.471 * \\
-(1.729)\end{array}$ & $\begin{array}{c}-4.889 \\
-(1.364)\end{array}$ & $\begin{array}{c}0.737 \\
(0.205)\end{array}$ & $\begin{array}{c}-2.771 \\
-(0.450)\end{array}$ & $\begin{array}{l}13.136 \\
(1.384)\end{array}$ \\
\hline FEATURED & $\begin{array}{c}7.603 \\
(0.329)\end{array}$ & $\begin{array}{l}29.823 \\
(1.065)\end{array}$ & & & \\
\hline POSTDPRC & $\begin{array}{c}5.661 \\
(1.194)\end{array}$ & & $\begin{array}{c}6.949 \\
(1.072)\end{array}$ & $\begin{array}{c}20.751^{*} \\
(1.668)\end{array}$ & $\begin{array}{l}42.044 \\
(1.474)\end{array}$ \\
\hline STRTBYNW & $\begin{array}{c}-71.966^{* * *} \\
-(3.812)\end{array}$ & & & & \\
\hline BYNOWPRC & $\begin{array}{c}0.328 * * * \\
(3.952)\end{array}$ & & $\begin{array}{c}0.284 * * * \\
(2.800)\end{array}$ & $\begin{array}{c}0.290 * * * \\
(3.291)\end{array}$ & \\
\hline (P)DURATION & $\begin{array}{c}0.748 \\
(1.421)\end{array}$ & $\begin{array}{c}1.082 \\
(1.429)\end{array}$ & $\begin{array}{c}2.132 \\
(0.847)\end{array}$ & $\begin{array}{c}3.871 \\
(1.288)\end{array}$ & $\begin{array}{c}2.628 \\
(0.917)\end{array}$ \\
\hline PENDBYNW & $\begin{array}{c}-7.796 \\
-(1.590)\end{array}$ & & $\begin{array}{c}12.873^{* *} \\
(2.085)\end{array}$ & & \\
\hline PNUMBIDS & $\begin{array}{c}2.830^{* *} \\
(2.293)\end{array}$ & $\begin{array}{c}3.997 * * * \\
(2.735)\end{array}$ & $\begin{array}{l}1.373^{*} \\
(1.704)\end{array}$ & $\begin{array}{l}1.791^{*} \\
(1.958)\end{array}$ & $\begin{array}{c}-0.523 \\
-(0.344)\end{array}$ \\
\hline PNUMBDRS & $\begin{array}{l}-3.085 \\
-(1.397)\end{array}$ & $\begin{array}{l}-5.294 * * \\
-(2.047)\end{array}$ & $\begin{array}{c}4.436 * * \\
(1.960)\end{array}$ & $\begin{array}{c}4.919 * * \\
(2.137)\end{array}$ & $\begin{array}{c}11.408 * * \\
(2.206)\end{array}$ \\
\hline R-Squared & 0.3301 & 0.0188 & 0.6685 & 0.3295 & 0.2645 \\
\hline Sample Size & 722 & 510 & 212 & 121 & 91 \\
\hline
\end{tabular}


We conclude this section with several other observations on the results. Homepage links appear to raise price mainly in the last sub-sample. Other minor seller choices - secure payment, use of an image, buying a "featured" listing, and description length - all appear to have minor effects on the final price. Except in the last sub-sample, choosing a private reserve price appears to increase final sales price substantially. However, as noted in an earlier section, this does not imply that it increases seller revenue, because a private reserve price also reduces the probability of selling the item. ${ }^{5}$ The square of the starting price was included to account for a non-linear relationship between the starting price and the final price. This non-linear relationship appears to be consistently significant and positive but is only significant at the $5 \%$ level in our 2SLS results, for the sample as a whole. In the case of all 'Buy it Now' auctions (column 3), the estimated effect on the final price of ending with the 'Buy it Now' price being taken was significant and positive in our 2SLS results. Using "Buy it Now" to effectively post a price appears to consistently have a positive impact on the final price (columns $3-5$ ) but the impact is not significant. ${ }^{6}$ Finally, the number of bids appears to push the price up slightly overall, and more so in the auctions that do not offer the 'Buy it Now' option. Of course, this effect is absent when the item is sold through the option being accepted, since then the number of bids is almost always one.

\section{Conclusion}

This paper has focused on the impacts of combining different market institutions for price determination, leading to what we have termed hybrid institutions. The fluid and dynamic nature of e-commerce presents fertile ground for research seeking to better understand the nature and influence of institutions on market behavior and design. Specifically, we empirically examined the design and outcomes of a set of auctions conducted on the Internet through eBay's online service. We first examined the impact of various seller characteristics on the seller's choice of auction features. We examined aspects such as starting price, use of a private reserve, length, and types and amount of information and services provided by the seller.

A major focus of our empirical analysis was the determinants of the seller's choice of whether to use a 'Buy it Now' option, which allows a buyer to essentially bypass the entire auction process. Sellers who used this option were characterized by higher seller ratings. This was true in our sample even across a wide range of selling frequencies. That is, even less experienced sellers appeared to be willing and able to use this hybrid institution effectively. Additionally, 'Buy it Now' was used widely across most product characteristics, i.e., no particular type or condition of the product appeared to favor the seller's use of the 'Buy it Now' option. The notable exception to this was that sellers in our sample who wished to sell a larger quantity of items in a single auction eschewed using 'Buy it Now'.

\footnotetext{
${ }^{5}$ A caveat is in order here, since eBay sellers have one free resale-try when their auction is unsuccessful. The impact on final price must also be judged in terms of the seller's overall wealth, which is not observable.

${ }^{6}$ The sub-sample where the 'Buy it Now' option was not accepted, appears to be an exception, since here it was marginally significant. However, only one auction in this sub-sample of 121 auctions featured the seller using 'Buy it Now' to effectively post a price, so the conclusion stands.
} 
Looking at other aspects of seller choices, auctions with damaged items or run by frequent sellers tended to have lower starting prices. A private reserve price was less likely to be used for new items, and by frequent sellers, and more likely by sellers with home pages. The latter were more likely to use secure payment options, as were sellers with higher ratings, and sellers of new items. Sellers with home pages gave longer descriptions, but the impact of seller reputation on descriptions was ambiguous. Photographs were provided more often by sellers with home pages, with higher reputations, and greater frequency of sales.

An important follow-on decision, if the 'Buy it Now' option was chosen, was the setting of the starting price. By choosing a starting price equal to the 'Buy it Now' price, a seller was able to make a posted price offer, making the auction format irrelevant. Again, we found that sellers with higher seller ratings and a higher frequency of selling in our sample were more likely to choose this posted price option. Additionally, sellers appeared less likely to post a price if the item was new.

Next, we examined to impact of the set of seller, product and auction characteristics on the conduct and outcome of the auction. The conduct of the auction was described by the number of bids and the number of unique bidders. The outcome was captured solely in the final selling price, since we focused on completed auctions. Since the conduct variables affecting the outcome were endogenous we used a 2SLS to estimate the structural equations. We found that the characteristics of the good were reflected in the final price, with new items fetching a higher price and damaged items fetching a lower price. Most interestingly, less experienced sellers received lower prices, on average, unless they effectively posted a price, but seller reputation, as measured by eBay's feedback ratings, did not appear as significant in determining the final price as we would have expected. Additionally, providing more information about him or herself generally boosted the final price for the seller, as did maintaining a private reserve price, as long as the auction resulted in a sale.

Again, our primary focus was on the effect of choosing to make the 'Buy it Now' option available. This appeared to have a large, significant, negative impact on the final price, on average. Additionally, if a seller did make a 'Buy it Now' option available, then setting a higher 'Buy it Now' price had a quantitatively small, but statistically significant, positive impact on the final price, ceteris paribus. Finally, the results on the conduct of the auction were mixed across the different sub-samples that we tested. The number of bids appeared to have had a consistent, significantly positive impact on the final price, while the number of unique bidders did not.

Our results show that there are systematic factors that determine the structure, conduct and outcome of online auctions. Our analysis suggests that sellers try to design their auctions - within the limits of eBay's format - to make them attractive to buyers in ways that increase the final sales price. In particular, low starting prices are used to generate more active auctions, which tend to push up final sales prices. Additionally, our companion paper (Anderson, et. al. 2004) examines how such a strategy may be lessfrequently chosen by less-experienced sellers or sellers who have only a few items to sell on eBay. In this paper, the use of the 'Buy it Now' option was possibly related to seller 
impatience, though it may have been used by experienced sellers, who wished to take advantage of eBay's large community of shoppers but wanted to sell at posted prices. The subsequent purchase and incorporation of Half.com into eBay may have provided an alternative for such sellers, but they can also continue to use the eBay site simultaneously, since listing costs are quite low.

We also found that information was far from perfect in Internet transactions. The characteristics of the good (newness, nature of accessories, etc.) were sometimes not completely clear, and the characteristics of the seller were also subject to interpretation. In particular, seller reputation did not always have clear or expected impacts on auction outcomes. Again, further analysis of the seller characteristics and choices represented in a related data set can be found in Anderson, et. al. (2004), and remains an area for further research.

\section{References}

Anderson, S., Friedman, D., Milam, G., and N. Singh, 2004, Seller Strategies on eBay, , UCSC Working Paper, April.

Bajari, P. and A. Hortaçsu (2003), The Winner's Curse, Reserve Prices and Endogenous Entry: Empirical Insights from eBay Auctions, Rand Journal of Economics, 34 (2): 329-355.

Bulow, Jeremy and Paul Klemperer. 1996. Auctions Versus Negotiations, American Economic Review, 86, 1, 180-194.

Budish, E. B. and Takeyama, I.N. 2001. "Buy Prices in Online Auctions: Irrationality on the Internet?” Economics Letters 72, 325-333.

Campbell, Colin M. and Dan Levin 2002. "When and Why Not to Auction," Working Paper, Rutgers and Ohio State.

Cason, T. and Friedman, D. 1993. An Empirical Analysis of Price Formation in Double Auction Markets. Addison-Wesley, Redwood City, CA.

Cason T. and Friedman, D. 1996. Price Formation in Double Auction Markets. Journal of Economic Dynamics and Control (20): 1307-1337.

Cason T. and Friedman D. 2002. A Laboratory Study of Customer Markets. Advances in Economic Analysis \& Policy: Vol. 2: No. 1, Article 1.

Cason, T., Friedman, D., and Milam, G. 2003. Bargaining Versus Posted Price Competition in Customer Markets. International Journal of Industrial Organization. (21): 223-251.

Fudenberg, Drew and Jean Tirole, (1983), Sequential Bargaining with Incomplete Information, Review of Economics Studies, 50, 221-247. 
Fudenberg, Drew and Jean Tirole, 1991, Game Theory, Cambridge, MA: MIT Press.

Gale, Douglas 1987. Limit Theorems for Markets with Sequential Bargaining. Journal of Economic Theory. pp. 20-54.

Garman, Mark. Market Microstructure, Journal of Financial Economics 3, 1976, pp. 257275.

Hof, Robert D. (2003) The eBay Economy, Business Week, August 25, 2003, http://www.businessweek.com:/print/magazine/content/03_34/b3846650.htm?mz

Holt, Charles A. (1995) "Industrial Organization: A Survey of Laboratory Research," in J. Kagel and A. Roth (eds.), Handbook of Experimental Economics, Princeton: Princeton University Press, 349-443.

Katkar, R. and Lucking-Reiley, D. 2000. Public Versus Secret Reserve Prices in eBay Auctions: Results from a Pokemon Field Experiment. Vanderbilt University Working Paper.

Klemperer, Paul. 2002, What Really Matters in Auction Design Journal of Economic Perspectives,. Volume? Pages??

Lancaster, K., 1971, Consumer Demand: A New Approach, New York: Columbia University Press.

Lucking-Reiley, D. 1999. Using Field Experiments to Test Equivalence Between Auction Formats: Magic on the Internet. American Economic Review (89): 1063-1080.

Lucking-Reiley, D., Bryan, D., Prasad, N., and Reeves, D. 2000. Pennies from eBay: The Determinants of Price in Online Auctions. Vanderbilt University Working Paper.

McAfee, R. P., and McMillan, J., (1987), "Auctions and Bidding," Journal of Economic Literature, 25, 699-738.

Morgan, John and Michael R. Baye, (2001), "Information Gatekeepers on the Internet and the Competitiveness of Homogeneous Product Markets," American Economic Review, 91, 454-74.

Ockenfels, Alex and Alvin Roth, (2004), "Late and Multiple Bidding in Second Price Internet Auctions: Theory and Evidence Concerning Different Rules for Ending an Auction," Games and Economic Behavior, forthcoming.

Resnick, Paul, Richard Zeckhauser, John Swanson, and Kate Lockwood, 2003, The Value of Reputation on eBay: A Controlled Experiment, http://www.si.umich.edu/ presnick/papers/postcards/. 
Reynolds, S. and John Wooders, 2003, “Auctions with a Buy Price”, University of Arizona Working Paper, http://aris.ss.uci.edu/econ/swetconf/Wooders.pdf

Riley, J. and Zeckhauser, R. 1983. Optimal Selling Strategies: When to Haggle, when to Hold Firm. Quarterly Journal of Economics (98): 267-289.

Rosen, Sherwin, 1974, "Hedonic Prices and Implicit Markets: Product Differentiation in Pure Competition," Journal of Political Economy, Jan.-Feb., 82 (1), 34-55.

Roth, Alvin E. and Axel Ockenfels (2002) "Last-Minute Bidding and the Rules for Ending Second-Price Auctions: Evidence from eBay and Amazon Auctions on the Internet", American Economic Review, 92, 4, 1093-1103.

Rubinstein, Ariel and Asher Wolinsky, 1987, Middlemen, Quarterly Journal of Economics, 102, 581-594.

Rubinstein, Ariel and Asher Wolinsky, 1990, "Decentralized Trading, Strategic Behavior and the Walrasian Outcome," Review of Economic Studies 57, 63-78.

Smith, Michael D., Joseph Bailey, and Erik Brynjolfsson. 2000. Understanding Digital Markets: Review and Assessment, in Brynjolfsson and Kahin eds. Understanding the Digital Economy, MIT Press, Cambridge, MA, 99-136.

Spulber, Daniel F., 1996a, Market Making by Price-Setting Firms, Review of Economic Studies, 63, pp. 559-580.

Spulber, Daniel F., 1996b, Market Microstructure and Intermediation, Journal of Economic Perspectives, volume 10, Summer, pp. 135-152.

Spulber, Daniel F., 1999, Market Microstructure: Intermediaries and the Theory of the Firm, New York: Cambridge University Press.

Stoll, Hans R. 2003. "Market Microstructure", in Handbook of the Economics of Finance. Edited by G.M. Constantinides, et al. North-Holland.

U.S. Census Bureau, 2004, "Retail E-Commerce Sales in Fourth Quarter 2003 Were 17.2 Billion, Up 25.1 Percent from Fourth Quarter 2002, Census Bureau Reports," http://www.census.gov/mrts/www/current.html 


\section{Appendix}

\section{Table A1: Variable Names and Definitions}

\begin{tabular}{|c|c|}
\hline Variable & Description \\
\hline NEW & $\begin{array}{l}\text { Dummy variable equal to one, if the item is definitively described to be "sealed, in the box, and new" in either } \\
\text { the title of the auction listing or in the description text. }\end{array}$ \\
\hline DAMAGE & $\begin{array}{l}\text { Dummy variable equal to one, if any significant damage to the item is mentioned in either the title or the } \\
\text { description text. }\end{array}$ \\
\hline EXTRAS & $\begin{array}{l}\text { Dummy variable equal to one, if the item is being offered with significant accessories, mentioned in either the } \\
\text { title or the description text. }\end{array}$ \\
\hline QUANTITY & Number of items sold in a single, particular auction. \\
\hline DAYS806 & Number of days between the start of the auction and the date of the first auction in the sample $(8 / 6 / 01)$. \\
\hline SINGLSR & Dummy variable equal to one, if the seller only held one auction during our sample. \\
\hline MULTSLR & $\begin{array}{l}\text { Dummy variable equal to one, if the seller held more than one auction but no more than ten auctions during } \\
\text { our sample. }\end{array}$ \\
\hline FREQSLR & $\begin{array}{l}\text { Dummy variable equal to one, if the seller held more than ten auctions but no more than fifty auctions during } \\
\text { our sample. }\end{array}$ \\
\hline RETAILER & Dummy variable equal to one, if the seller held more than fifty auctions during our sample. \\
\hline LNSLRTNG & $\begin{array}{l}\text { This is the natural logarithm of the difference between the number of unique, positive comments about the } \\
\text { seller and the number of unique, negative comments. }\end{array}$ \\
\hline NEGRATIO & $\begin{array}{l}\text { The ratio of the number of unique, negative comments to the total number of unique comments listed in the } \\
\text { seller's feedback page. }\end{array}$ \\
\hline SLRHOME & $\begin{array}{l}\text { Dummy variable equal to one, if the seller posts a link to his website in the description text of the auction } \\
\text { listing. }\end{array}$ \\
\hline STARTPRC & Initial price to start the bidding, posted by the seller at the beginning of the auction. \\
\hline SQRSTPRC & Square of the seller's starting price. \\
\hline LOWSTPRC & Dummy variable equal to one, if the seller posts an initial price below twenty dollars. \\
\hline POSTDPRC & Dummy variable equal to one, if the seller sets the initial price equal to a displayed, 'Buy it Now' price. \\
\hline STRTBYNW & $\begin{array}{l}\text { Dummy variable equal to one, if the seller offers buyers the option to buy the item immediately at a displayed, } \\
\text { 'Buy it Now' price. }\end{array}$ \\
\hline BYNOWPRC & Seller's price if displayed at the beginning of the auction as a 'Buy it Now' offer. \\
\hline PRIVTRES & $\begin{array}{l}\text { Dummy variable equal to one, if the seller displays a notice that actual sale is subject to a buyer at least } \\
\text { bidding as high as some unknown, private, reserve price. }\end{array}$ \\
\hline FEATURED & $\begin{array}{l}\text { Dummy variable set equal to one, if the seller paid extra to have the item(s) listed at the top of the listings, no } \\
\text { matter what the potential buyer's search criteria was. }\end{array}$ \\
\hline DSCLNGTH & $\begin{array}{l}\text { Number of text characters in the description of the item, composed by the seller for the auction listing page, } \\
\text { minus the number of HTML tags. }\end{array}$ \\
\hline IMAGE & Dummy variable set equal to one, if the seller included at least one image in the description of the item. \\
\hline SCRPYDUM & Dummy variable set equal to one, if the seller accepts credit cards, PayPal, or eBay Online Payments. \\
\hline DURATION & Duration of the auction, initially set by the seller to a maximum of $3,5,7$, or 10 days. \\
\hline ENDBYNOW & Dummy variable equal to one, if the auction ends with a buyer accepting a seller's 'Buy it Now' option. \\
\hline NUMBIDS & Number of bids on the item(s) in a particular auction. \\
\hline UNIQBIDR & Number of unique bidders for the item(s) in a particular auction. \\
\hline WINBID & Dollar value of the final bid in an auction that resulted in a sale. \\
\hline
\end{tabular}




\section{OLS Regression Results}

Table A2 presents the OLS regression results for these auctions and bids. The first three variables in each regression are characteristics of the item. The fourth variable indicates the quantity of items sold in a single auction. The fifth variable is the trend variable, controlling for relative time of entry into our sample period. The next four variables capture seller characteristics and the subsequent twelve variables indicate seller choices, including the square of the starting price to control for some non-linearity component present in this seller choice. The final four variables are endogenous variables that capture various facets of the conduct of the auction. In particular, ENDBYNOW is a dummy variable capturing whether the auction ended with the acceptance of the 'Buy it Now' option or not. The other variables capture the duration (endogenous in the case of 'Buy it Now' auctions), the number of bids made, and the number of bidders.

SRTBYNW is a critical variable, reflecting the decision whether to use the 'Buy it Now' option or not. Note that when the 'Buy it Now' option is accepted, the 'Buy it Now' price is identical to the winning bid, the dependent variable in these regressions. In order to appropriately control for such endogeneity in the entire sample and in each subsample we have utilized 2SLS, as reported in the main text. For the OLS regressions we employ alternative methods, such as setting the 'Buy it Now' price, BYNOWPRC, equal to zero if there is no 'Buy it Now' option.

In both our OLS and 2SLS results, it appears that non-frequent sellers tend to get lower prices for their items when there is no 'Buy it Now' option chosen by the seller, relative to frequent sellers (the omitted category of sellers selling 11-50 times in our sample). This effect is significantly reversed when the seller makes the 'Buy it Now' option available and accepted by the buyer. Again, all but one seller in this 'Buy it Now'-accepted sub-sample is effectively posting a price, so one should look at a 'no sale' as the alternative to acceptance of the 'Buy it Now' option for this sub-sample. Without considering the likelihood of 'no sale', it may initially appear as if a consequence of not posting a price is to end up selling the item for less, for inexperienced sellers in our sample.

However, since the alternatives are different for buyers in the non-'Buy it Now' vs. "posted price" sub-samples it is interesting to more deeply consider the selling strategies of relatively inexperienced sellers in our sample. About $85 \%$ of all 'no sales' in our sample occurred for items being offered by inexperienced sellers, although none of these actually posted a price. Additionally, about the same proportion of auctions that ended in no sale in our sample started with the 'Buy it Now' option as those that did end in a sale. So, it appears that inexperienced sellers understood how to use the 'Buy it Now' option and only used it to effectively post a price when protecting their price in this way would probably not result in losing the sale. Since this is a "take it or leave it" offer by the seller, this strategy can only boost the average final price in our regressions because no auction occurs, and the number of bids cannot be depressed. 
Table A2: OLS Regressions of Outcome (Value of Winning Bid)

\begin{tabular}{|c|c|c|c|c|c|}
\hline Variable & All Sales & No BuvNow & Onlv BuvNow & BuvNow Rei. & BuvNow Acc. \\
\hline \multirow[t]{2}{*}{ NEW } & $7.825 * * *$ & $9.133 * * *$ & $6.005 * *$ & $10.402 * * *$ & 13.847 \\
\hline & $(4.243)$ & $(3.602)$ & $(2.556)$ & $(2.980)$ & $(1.662)$ \\
\hline \multirow[t]{2}{*}{ DAMAGE } & $-21.451 * *$ & $-27.274 * *$ & $-9.053 *$ & 4.215 & $-41.306 * * *$ \\
\hline & $-(2.295)$ & $-(2.014)$ & $-(1.873)$ & $(0.392)$ & $-(3.439)$ \\
\hline \multirow[t]{2}{*}{ EXTRAS } & $5.190 * * *$ & $9.606 * * *$ & -0.191 & -1.474 & 7.153 \\
\hline & $(2.654)$ & $(2.927)$ & $-(0.094)$ & $-(0.475)$ & $(0.761)$ \\
\hline \multirow[t]{2}{*}{ QUANTITY } & $-5.256 * * *$ & $-5.298 * * *$ & -2.802 & -4.690 & \\
\hline & $-(5.583)$ & $-(5.232)$ & $-(1.070)$ & $-(1.228)$ & \\
\hline \multirow[t]{2}{*}{ DAYS806 } & $-0.192 *$ & $-0.293 * *$ & 0.019 & 0.135 & 0.005 \\
\hline & $-(1.898)$ & $-(2.220)$ & $(0.186)$ & $(0.743)$ & $(0.014)$ \\
\hline \multirow[t]{2}{*}{ SINGLSLR } & $-5.712 * *$ & $-9.412 * * *$ & 3.919 & 7.082 & $36.485 * * *$ \\
\hline & $-(2.366)$ & $-(2.590)$ & $(0.901)$ & $(1.058)$ & $(2.929)$ \\
\hline \multirow[t]{2}{*}{ MULTSLR } & $-9.147 * * *$ & $-13.055 * * *$ & 1.364 & -0.382 & $32.297 * *$ \\
\hline & $-(3.463)$ & $-(3.695)$ & $(0.337)$ & $-(0.058)$ & $(2.608)$ \\
\hline \multirow[t]{2}{*}{ NEGRATIO } & $-33.900 *$ & $-40.149 *$ & -41.392 & 51.840 & $-442.377 * * *$ \\
\hline & $-(1.693)$ & $-(1.756)$ & $-(0.904)$ & $(0.721)$ & $-(4.172)$ \\
\hline \multirow[t]{2}{*}{ LNSLRTNG } & $-1.886 * * *$ & $-2.155 * * *$ & $-1.420 * *$ & $-3.717 * * *$ & 0.267 \\
\hline & $-(3.673)$ & $-(3.061)$ & $-(2.027)$ & $-(3.197)$ & $(0.167)$ \\
\hline \multirow[t]{2}{*}{ SLRHOME } & -1.211 & -0.801 & 2.298 & -0.358 & $27.965 * * *$ \\
\hline & $-(0.369)$ & $-(0.143)$ & $(0.960)$ & $-(0.072)$ & $(3.340)$ \\
\hline \multirow[t]{2}{*}{ STARTPRC } & $-0.248 * *$ & -0.223 & -0.288 & -0.125 & \\
\hline & $-(2.325)$ & $-(1.510)$ & $-(1.440)$ & $-(0.427)$ & \\
\hline \multirow[t]{2}{*}{ SQRSTPRC } & $0.0019 * * *$ & $0.0018 * * *$ & $0.0019 * * *$ & 0.001 & \\
\hline & $(5.038)$ & $(3.027)$ & $(3.026)$ & (1.399) & \\
\hline \multirow[t]{2}{*}{ LOWSTPRC } & -7.556 & -6.646 & -1.824 & 7.547 & \\
\hline & $-(1.112)$ & $-(0.782)$ & $-(0.130)$ & $(0.411)$ & \\
\hline \multirow[t]{2}{*}{ PRIVTRES } & $9.068 * * *$ & $9.025 * * *$ & 2.339 & 5.839 & -3.456 \\
\hline & $(4.255)$ & $(2.816)$ & $(0.926)$ & (1.040) & $-(0.312)$ \\
\hline \multirow[t]{2}{*}{ DSCLNGTH } & $0.0009^{*}$ & $0.0012 *$ & 0.000 & 0.001 & 0.000 \\
\hline & $(1.847)$ & $(1.859)$ & $(1.336)$ & $(1.567)$ & $(0.322)$ \\
\hline \multirow[t]{2}{*}{ IMAGE } & 0.818 & -0.275 & 0.430 & 1.106 & 12.695 \\
\hline & $(0.257)$ & $-(0.069)$ & $(0.175)$ & $(0.252)$ & $(1.281)$ \\
\hline \multirow[t]{2}{*}{ SCRPYDUM } & $-5.729 * *$ & $-5.930 *$ & -2.961 & -8.023 & 11.925 \\
\hline & $-(2.276)$ & $-(1.773)$ & $-(1.161)$ & $-(1.642)$ & $(1.382)$ \\
\hline \multirow[t]{2}{*}{ FEATURED } & -4.599 & -1.772 & & & \\
\hline & $-(0.448)$ & $-(0.152)$ & & & \\
\hline \multirow[t]{2}{*}{ POSTDPRC } & $14.222 * * *$ & & $18.045^{*}$ & $17.978 *$ & $38.865^{*}$ \\
\hline & $(2.848)$ & & $(1.898)$ & $(1.955)$ & $(1.764)$ \\
\hline \multirow[t]{2}{*}{ STRTBYNW } & $-356.05 * * *$ & & & & \\
\hline & $-(3.785)$ & & & & \\
\hline BYNOWPRC & $0.291 * * *$ & & $0.337 * * *$ & $0.286 * * *$ & \\
\hline & $(3.792)$ & & $(3.350)$ & $(2.764)$ & \\
\hline ENDBYNOW & $-19.776 * * *$ & & -14.337 & & \\
\hline & $-(4.259)$ & & $-(1.638)$ & & \\
\hline DURATION & 0.223 & 0.615 & 0.041 & -0.009 & -0.727 \\
\hline & $(0.451)$ & $(0.912)$ & $(0.079)$ & $-(0.012)$ & $-(0.500)$ \\
\hline NUMBIDS & $1.022 * * *$ & $1.058 * * *$ & $0.959 * *$ & $0.987 * *$ & 0.577 \\
\hline & $(4.158)$ & $(3.833)$ & $(2.185)$ & $(2.186)$ & $(0.693)$ \\
\hline UNIQBIDR & -0.201 & -0.308 & 0.531 & 0.832 & $3.961^{*}$ \\
\hline & $-(0.450)$ & $-(0.612)$ & $(0.619)$ & $(0.863)$ & $(1.678)$ \\
\hline R-Squared & 0.4071 & 0.2532 & 0.8278 & 0.6797 & 0.3783 \\
\hline Sample Size & 722 & 510 & 212 & 121 & 91 \\
\hline
\end{tabular}

Notes: (1) 1 to 3 asterisks represent 10, 5, 1\% significance, respectively. (2) In the last sub-sample QUANTITY is omitted because it is always equal to 1 as is any variable calculated on the basis of the starting price, because the starting price is identical to the winning bid 
However, from our analysis of conditional means (not reported) for the non-'Buy it Now' sub-sample, it appears that less experienced sellers started their auctions with prices that were over $\$ 41$ higher, on average, than did more frequent sellers in the same sub-sample. Also, this inexperienced group appears to have attracted about 9 less bids and 6 fewer bidders per auction than frequent sellers, within the same non-'Buy it Now' sub-sample. Thus, inexperienced sellers may be dampening enthusiasm concerning their auctions by starting the bidding at a higher price than more experienced sellers in our sample, even without further reducing bidder interest by holding a private reserve auction or by utilizing the 'Buy it Now' option to effectively post a price which might be "too high". The regression analysis suggests that less-frequent sellers choose more often to start auctions at a higher starting price, which may be working by decreasing the excitement surrounding their auctions to cause their auctions to end with lower final bids, on average, in the non-'Buy it Now' sub-sample, as seen in the results in Tables A2 and 5 .

For the OLS results in Table A2 and the 2SLS results in Table 5, LNSLRTNG has a negative, significant coefficient for the entire sample and for every sub-sample, except for where a 'Buy it Now' option was accepted. An auction does not really occur for this last sub-sample and it appears that the seller's rating did not significantly affect the level of the "posted price", while the ratio of negative comments in a seller's feedback listings appears to have had a significant, negative effect on this price, chosen by the seller. The magnitudes of the coefficients on NEGRATIO appear quite large due to the very small units of measurement for this variable. For instance, the mean value of NEGRATIO in the 'Buy it Now'-accepted sub-sample was 0.017. Across the other two sub-samples, where a 'Buy it Now' option was not available, and where it was available but not accepted, we may have a negative bias due to the omission of the frequent seller category, that is supporting a weak, negative correlation of LNSLRTNG with WINBID (Rho $=-0.12$ for the entire sample). LNSLRTNG has a positive correlation with FREQSLR (Rho $=0.07$ ), which in turn also has a weak, negative correlation with WINBID (Rho $=-0.05$ ). Additionally, we are left with the possibility of bias affecting our results through one of the endogenous variables, which we examine with the 2SLS results for those variables.

\section{First-Stage Regression Results for 2SLS}

How exogenous characteristics and seller choices affect our regression results through the endogenous conduct of the auction may be explored further through our firststage regression results, which we present in Tables A3 and A4. In Table A3, for the sample as a whole and for auctions where a 'Buy it Now' option was not made available, the characteristics of the goods have the expected impacts on the number of bids and bidders, and on whether a 'Buy it Now' option was accepted.

Amongst seller characteristics the most interesting first-stage results are that the proportion of negative comments in the seller's rating appears to have a significant positive impact on both the number of bids and the number of unique bidders for the sample as a whole, and for the sub-sample where the 'Buy it Now' option was not available. At the same time, the log of the seller rating was insignificant. This is 
consistent with our earlier suggestion that negative comments appear to be effectively hidden on the separate seller ratings page, or swamped by positive comments for more frequent sellers/buyers, or are so strongly correlated with the sellers' ratings (experience) that it can appear to have a significant, positive impact on the final price in our final regressions and with the number of bids and bidders in these first-stage regressions.

The most interesting results on seller choices in Table A3 also support our earlier suggestion of the likely decrease in enthusiasm from bidders if the seller chooses a high starting price or chooses a private reserve price. Both of these choices appear to have a significant, negative impact on the number of bids and of bidders for our sample as a whole as well as for the non-'Buy it Now' sub-sample. We have argued that such choices appear to mostly occur among the relatively inexperienced sellers in our sample. Additionally, the choice to pay eBay an additional fee to feature an item, though undertaken by almost no sellers in our sample, does appear to have had a significant, positive impact in attracting both more bids and bidders.

With respect to our focus on the 'Buy it Now' institution, the most interesting result is significant negative impact of the seller's choice to make the 'Buy it Now' option available, on the number of bids. This choice also has a large, negative impact on the number of bidders but this result is statistically insignificant. Also, as we have mentioned, almost no 'Buy it Now' option was accepted unless the seller chose to use "Buy it Now" to effectively post a price. This characteristic of the auctions in our sample is again reflected in Table A3 by the strong, significantly positive coefficient on posting a price, for the endogenous outcome of the auction ending with the 'Buy it Now' option being accepted.

One should note from Table A4 that the duration of the auction is an additional endogenous variable in all auctions where the seller made a 'Buy it Now' option available. We expect chosen duration to be impacted in a similar manner by the product characteristics, seller characteristics, and seller choices, as are the other conduct variables, and this generally appears to be the case. New items enjoy significantly less time at auction before being purchased, on average, while damaged items spend relatively more time being bid upon. It appears more likely (Table A3) that a first bidder will cut the auction short and purchase a new item at the 'Buy it Now' price and it appears less likely that a first bidder will do so for a damaged item. Product characteristics are not as significant in explaining the duration of the auction for the sub-sample where the 'Buy it Now' option is not accepted, because auction duration reverts to whatever was initially chosen by the seller.

Selling frequencies are important seller characteristics that appear to significantly impact the auction duration. Both single sellers and slightly more experienced sellers appeared to have had significantly shorter auctions than more frequent sellers (the omitted category), whether their 'Buy it Now' price was accepted or not. In addition, there appear to be significant, negative impacts on the number of bidders and on the number of bids from being a less frequent seller for the sub-sample where the 'Buy it Now' option was accepted by the first bidder. However, this result is solely due to one auction in our sample with a buyer that "trembled" and bid above the "Buy it Now' price. Since the 'Buy it Now' price did not disappear in this case, it appears that another bidder then was able to actually underbid the first bidder and still win the item, according to 
eBay's rules for "Buy it Now". The seller for this particular auction appears to have been a more frequent seller but with a relatively high ratio of negative comments in his or her seller rating.

Clearly, if it were not for this one auction in our sample, we would expect the only significant endogenous impacts to occur on the auction duration and not on the number of bids or bidders in the sub-sample where the 'Buy it Now' option was accepted. The only other significant impacts on auction duration in this sub-sample are when the seller choosing to provide a link to his/her homepage, has a significant negative impact on the duration of the auction, and providing a photograph of the item, has an unexpected positive impact on auction duration (but is only marginally significant).

Overall, for the sub-sample where the 'Buy it Now' option was not accepted by the first bidder, most of the significant, impacts on endogenous variables appear to be on the number of bids, and not on the auction duration or the number of unique bidders, where the lack of impact on the auction duration is understandable, since duration reverts to the seller's initial choice. For this sub-sample, Table A9 presents results that indicate experience may have differing significant impacts on the duration of the auction vs. the number of bids or bidders. That is, less-experienced sellers appear to have set auction durations that were significantly shorter, yet attracted both significantly more bids and bidders, on average, than more frequent sellers in our sample.

Additionally, it again appears that lower starting prices can increase the participation in the auction, in terms of the number of bids, in this sub-sample where the 'Buy it Now' option was not accepted. Also, selling a greater quantity of Palm Pilot Vx's in a single auction tended to significantly decrease both the number of bids and bidders, while new items attracted significantly more bids and bidders in our sample.

While some of the coefficients in the non-'Buy it Now' regressions and the regressions that began with a 'Buy it Now' option but then proceeded as a regular auction are quite dissimilar, there are other similarities, and we therefore tested for a structural break using a likelihood ratio test. The results for both the OLS and 2SLS regressions indicate that the null hypothesis of no structural break could not be rejected. This would suggest that starting an auction with the 'Buy it Now' option may not have significant impacts on the outcome if the 'Buy it Now' option does not get invoked. On the other hand, the auctions that end with the 'Buy it Now' option seem to behave quite differently, as we have discussed. 
Table A3: First Stage Regressions for Instrumenting Conduct Variables

\begin{tabular}{|c|c|c|c|c|c|}
\hline & & All Auctions & & No "Buv it I & Iow" Option \\
\hline Variable & Num. of & Num. Bidders & End BuyNow & Num. of Bids & Num. Bidders \\
\hline NEW & $1.365 * *$ & 0.413 & -0.376 & 1.060 & 0.257 \\
\hline & $(2.233)$ & (1.429) & $-(0.455)$ & $(1.287)$ & $(0.639)$ \\
\hline DAMAGE & $-3.593 * *$ & -0.543 & -0.221 & $-3.737 * *$ & -0.916 \\
\hline & $-(2.267)$ & $-(0.659)$ & $-(0.079)$ & $-(2.273)$ & $-(1.385)$ \\
\hline EXTRAS & 0.168 & $-0.517 * *$ & -0.602 & 0.138 & $-0.582 *$ \\
\hline & $(0.312)$ & $-(2.047)$ & $-(0.791)$ & $(0.190)$ & $-(1.701)$ \\
\hline QUANTITY & $-8.980 * * *$ & $-4.713 * * *$ & & $-9.221 * * *$ & $-5.065 * * *$ \\
\hline & $-(3.670)$ & $-(3.462)$ & & $-(3.482)$ & $-(3.455)$ \\
\hline DAYS806 & 0.072 & 0.716 & $0.127 * * *$ & -3.963 & -0.369 \\
\hline & $(0.014)$ & $(0.278)$ & $(2.576)$ & $-(0.601)$ & $-(0.101)$ \\
\hline SINGLSLR & $6.462 * *$ & 2.610 & 1.353 & 6.569 & 1.818 \\
\hline & $(2.017)$ & $(1.562)$ & $(0.725)$ & $(1.414)$ & $(0.712)$ \\
\hline MULTSLR & 6.200 & 2.088 & 0.241 & 1.961 & -0.814 \\
\hline & $(1.487)$ & $(0.950)$ & $(0.138)$ & $(0.333)$ & $-(0.243)$ \\
\hline NEGRATIO & $73.522 * * *$ & $28.060 * * *$ & -17.641 & $90.722 * * *$ & $38.886^{* * *}$ \\
\hline & $(3.767)$ & $(3.289)$ & $-(1.025)$ & $(3.949)$ & $(3.754)$ \\
\hline LNSLRTNG & -0.844 & -0.347 & 0.411 & $-1.260 *$ & -0.595 \\
\hline & $-(1.352)$ & $-(1.097)$ & $(1.520)$ & $-(1.751)$ & $-(1.524)$ \\
\hline SLRHOME & -0.353 & -0.350 & 0.698 & -0.062 & 0.276 \\
\hline & $-(0.345)$ & $-(0.653)$ & $(0.613)$ & $-(0.036)$ & $(0.283)$ \\
\hline STARTPRC & $-0.649 * * *$ & $-0.452 * * *$ & $0.092 *$ & $-0.740 * *$ & $-0.347 * *$ \\
\hline & $-(3.102)$ & $-(4.891)$ & $(1.646)$ & $-(2.229)$ & $-(2.105)$ \\
\hline SQRSTPRC & $0.0009 * * *$ & $0.0005 * * *$ & -0.0002 & $0.0009 * *$ & 0.0003 \\
\hline & $(3.601)$ & $(4.893)$ & $-(0.981)$ & $(2.024)$ & (1.363) \\
\hline LOWSTPRC & 3.401 & $3.140 * * *$ & & 4.745 & $2.887 * *$ \\
\hline & $(1.178)$ & $(2.717)$ & & (1.393) & $(1.963)$ \\
\hline PRIVTRES & $-2.051 * * *$ & $-0.774 * * *$ & 1.580 & $-2.316 * * *$ & $-0.897 * * *$ \\
\hline & $-(3.535)$ & $-(2.884)$ & (1.497) & $-(3.213)$ & $-(2.634)$ \\
\hline DSCLNGTH & 0.0003 & -0.0003 & -0.0001 & 0.0002 & -0.0004 \\
\hline & $(0.359)$ & $-(0.905)$ & $-(0.683)$ & $(0.251)$ & $-(0.876)$ \\
\hline IMAGE & -0.493 & $-0.802 * *$ & 0.640 & $-2.087 * *$ & $-1.505 * * *$ \\
\hline & $-(0.641)$ & $-(2.217)$ & $(0.721)$ & $-(2.021)$ & $-(2.926)$ \\
\hline SCRPYDUM & -0.268 & 0.0614 & -0.011 & 0.271 & 0.262 \\
\hline & $-(0.356)$ & $(0.165)$ & $-(0.013)$ & $(0.293)$ & $(0.557)$ \\
\hline FEATURED & $57.538 * * *$ & $39.781 * * *$ & & $58.40 * * *$ & $40.873 * * *$ \\
\hline & (8.883) & $(10.437)$ & & $(8.348)$ & $(10.146)$ \\
\hline DURATION & -0.807 & -0.608 & & -2.180 & -1.586 \\
\hline & $-(0.383)$ & $-(0.582)$ & & $-(0.834)$ & $-(1.216)$ \\
\hline STRTBYNW & -375.06 & $-405.08 * * *$ & 7.84 & & \\
\hline & $-(0.975)$ & $-(2.670)$ & $(1.266)$ & & \\
\hline BYNOWPRC & 0.230 & 0.367 & -0.044 & & \\
\hline & $(0.364)$ & $(1.460)$ & $-(1.514)$ & & \\
\hline POSTDPRC & 0.412 & -0.012 & $8.873 * * *$ & & \\
\hline & $(0.277)$ & $-(0.015)$ & $(4.182)$ & & \\
\hline PENDBYNW & -0.309 & 0.035 & & & \\
\hline & $-(0.221)$ & $(0.045)$ & & & \\
\hline R Squared & 0.7672 & 0.8353 & & 0.7629 & 0.8377 \\
\hline Log-Likelihood & & & -32.846 & & \\
\hline Sample Size & 722 & 722 & 722 & 510 & 510 \\
\hline
\end{tabular}

Notes: (1) Coefficients are reported with t-statistics below in parentheses. (2) 1 to 3 asterisks represent 10, $5,1 \%$ significance, respectively. (3) The results for the number of bids and bidders are from OLS firststage regressions. The results for accepting "Buy it Now" are from a Logit regression 
Table A4: First Stage Regressions for Instrumenting Conduct Variables (continued)

\begin{tabular}{|c|c|c|c|c|c|c|}
\hline \multirow[b]{2}{*}{ Variable } & \multicolumn{3}{|c|}{ "Buy it Now" Accepted } & \multicolumn{3}{|c|}{ "Buy it Now" Not accepted } \\
\hline & $\begin{array}{l}\text { Auction } \\
\text { Duration }\end{array}$ & $\begin{array}{c}\text { Number of } \\
\text { Bids }\end{array}$ & $\begin{array}{l}\text { Number of } \\
\text { Bidders }\end{array}$ & $\begin{array}{l}\text { Auction } \\
\text { Duration }\end{array}$ & $\begin{array}{c}\text { Number of } \\
\text { Bids }\end{array}$ & $\begin{array}{c}\text { Number of } \\
\text { Bidders }\end{array}$ \\
\hline \multirow[t]{2}{*}{ NEW } & $-1.321 * * *$ & -0.888 & -0.592 & 0.499 & $3.083 * *$ & $0.996 * *$ \\
\hline & $-(2.666)$ & $-(1.278)$ & $-(1.657)$ & $(1.193)$ & $(2.571)$ & $(2.070)$ \\
\hline \multirow[t]{2}{*}{ DAMAGE } & $2.238 * * *$ & $4.019 * *$ & 1.794 & -0.935 & -3.897 & -0.559 \\
\hline & $(2.723)$ & $(2.135)$ & $(1.174)$ & $-(0.902)$ & $-(1.075)$ & $-(0.285)$ \\
\hline \multirow[t]{2}{*}{ EXTRAS } & -0.051 & -0.540 & -0.625 & 0.809 & -0.528 & -0.276 \\
\hline & $-(0.074)$ & $-(0.609)$ & $-(1.337)$ & $(1.313)$ & $-(0.424)$ & $-(0.514)$ \\
\hline \multirow[t]{2}{*}{ QUANTITY } & & & & 3.271 & $-14.117 *$ & $-12.919 * * *$ \\
\hline & & & & $(1.197)$ & $-(1.707)$ & $-(3.707)$ \\
\hline \multirow[t]{2}{*}{ DAYS806 } & -2.866 & 0.555 & 0.464 & -6.206 & 18.994 & $24.525 * * *$ \\
\hline & $-(0.872)$ & $(0.151)$ & $(0.238)$ & $-(1.120)$ & $(1.032)$ & $(3.285)$ \\
\hline \multirow[t]{2}{*}{ SINGLSLR } & $-15.989 * * *$ & $-39.774 * * *$ & $-12.165^{* *}$ & $-6.742 * * *$ & 9.823 & $7.587 * *$ \\
\hline & $-(3.014)$ & $-(3.676)$ & $-(2.566)$ & $-(2.901)$ & $(1.225)$ & $(2.354)$ \\
\hline \multirow{2}{*}{ MULTSLR } & $-15.023 * * *$ & $-34.905 * * *$ & $-7.713^{*}$ & $-10.633 * * *$ & $37.179 * * *$ & $17.281 * * *$ \\
\hline & $-(3.425)$ & $-(3.347)$ & $-(1.809)$ & $-(3.018)$ & $(3.899)$ & $(4.241)$ \\
\hline \multirow[t]{2}{*}{ NEGRATIO } & -4.483 & $189.636 * * *$ & $69.766 * * *$ & -39.903 & 45.184 & -34.150 \\
\hline & $-(0.178)$ & $(4.293)$ & $(3.634)$ & $-(0.949)$ & $(0.373)$ & $-(0.803)$ \\
\hline \multirow[t]{2}{*}{ LNSLRTNG } & -0.825 & -1.282 & -0.018 & -0.024 & -0.795 & 0.305 \\
\hline & $-(1.201)$ & $-(1.156)$ & $-(0.036)$ & $-(0.028)$ & $-(0.503)$ & $(0.372)$ \\
\hline \multirow[t]{2}{*}{ SLRHOME } & $-1.537 * *$ & -0.694 & -0.569 & -0.486 & 1.549 & -1.107 \\
\hline & $-(2.021)$ & $-(0.554)$ & $-(0.831)$ & $-(0.727)$ & $(0.673)$ & $-(1.031)$ \\
\hline \multirow[t]{2}{*}{ STARTPRC } & & & & -0.189 & -0.907 & $-0.715 * *$ \\
\hline & & & & $-(0.726)$ & $-(1.323)$ & $-(2.202)$ \\
\hline \multirow[t]{2}{*}{ SQRSTPRC } & & & & 0.000 & $0.0013^{*}$ & $0.001 * * *$ \\
\hline & & & & $(0.986)$ & $(1.732)$ & $(2.872)$ \\
\hline \multirow{2}{*}{ LOWSTPRC } & & & & -1.150 & 4.257 & 0.519 \\
\hline & & & & $-(0.276)$ & $(0.336)$ & $(0.094)$ \\
\hline \multirow[t]{2}{*}{ PRIVTRES } & 0.142 & $3.905 * * *$ & $1.976 * * *$ & -0.348 & -2.570 & $-1.356^{*}$ \\
\hline & $(0.295)$ & $(5.686)$ & $(5.854)$ & $-(0.564)$ & $-(1.327)$ & $-(1.676)$ \\
\hline \multirow[t]{2}{*}{ DSCLNGTH } & -0.0002 & -0.0007 & 0.0008 & 0.0004 & 0.0013 & -0.0003 \\
\hline & -0.131 & $-(0.359)$ & $(0.584)$ & $(0.573)$ & $(0.710)$ & $-(0.305)$ \\
\hline \multirow[t]{2}{*}{ IMAGE } & $1.085^{*}$ & -0.091 & 0.395 & -0.490 & $3.840^{*}$ & 0.787 \\
\hline & $(1.790)$ & $-(0.091)$ & $(0.866)$ & $-(0.589)$ & (1.781) & (1.031) \\
\hline \multirow[t]{2}{*}{ SCRPYDUM } & 0.366 & -1.177 & $-0.849 *$ & -0.497 & -2.028 & 0.004 \\
\hline & $(0.653)$ & $-(1.389)$ & $-(1.777)$ & $-(1.060)$ & $-(1.304)$ & $(0.007)$ \\
\hline \multirow[t]{2}{*}{ BYNOWPRC } & & & & 0.140 & -0.333 & 0.036 \\
\hline & & & & $(0.415)$ & $-(0.272)$ & $(0.091)$ \\
\hline \multirow[t]{2}{*}{ POSTDPRC } & 1.131 & -1.200 & -0.385 & -2.150 & 2.442 & 0.142 \\
\hline & $(0.533)$ & $-(0.855)$ & $-(0.415)$ & $-(1.281)$ & $(0.499)$ & $(0.068)$ \\
\hline R Squared & 0.3542 & 0.7178 & 0.6766 & 0.4183 & 0.6884 & 0.7116 \\
\hline Sample Size & 91 & 91 & 91 & 121 & 121 & 121 \\
\hline
\end{tabular}

Notes: See Table A3 